\title{
Analisis Manajemen Dalam Pengembangan Kompetensi Pendidik Madrasah Tsanawiyah
}

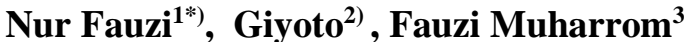 \\ ${ }^{1,2,3}$ Institut Agama Islam Negeri Surakarta \\ *Email korespondensi: penulis nurfaizi01@gmail.com
}

\begin{abstract}
Management in madrasah education, in addition to the role of the principal, is also the role of supervisors or supervisors who are also a determinant in improving learning achievement and school quality. Education supervision or supervision is an effort to provide services to education stakeholders, especially to educators at school, both individually and in groups to improve the quality of the learning process and results, the purpose of this study is to conduct management analysis for the development of educational competence in madrasah tsanawiyah in Demak district. This research method, carried out through a qualitative approach using descriptive method of case study strategies. This study describes or describes the phenomenon of teacher competency development in classroom management. The results showed that in Madrasah Tsanawiyah, Demak Regency, showed that policies made both from planning, implementation, support and obstacles, and the impact of developing teacher professional competence which were carried out were carried out according to goals and planned although there were still obstacles and shortcomings that still had to be addressed.
\end{abstract}

Keywords : Manajemen, Madrasah Tsanawiyah, Educator Competence.

Saran sitasi: Fauzi, N., Giyoto., \& Muharrom, F. (2021). Analisis Manajemen Dalam Pengembangan Kompetensi Pendidik Madrasah Tsanawiyah. Jurnal Ilmiah Ekonomi Islam, 7(01), 433-442. doi:http://dx.doi.org/10.29040/jiei.v7i1.2250

DOI: http://dx.doi.org/10.29040/jiei.v7i1.2250

\section{PENDAHULUAN}

Manajemen pendidikan di Indonesia, sekarang ini dihadapkan pada berbagai permasalahan yang amat berat, khususnya dalam upaya menyiapkan kualitas sumber daya manusia agar mampu bersaing di era global yang sangat kompetitif. Permasalahan yang dihadapi dari tudingan rendahnya kualitas output sampai dengan kerusakan moral masyarakat akibat gagalnya pendidikan dalam membangun nilai-nilai yang semestinya tidak terpisahkan dengan pendidikan.

Kurikulum 2013 merupakan pengembangan dari kurikulum sebelumnya untuk merespon berbagai tantangan internal dan eksternal. Titik tekan pengembangan Kurikulum 2013 adalah penyempurnaan pola pikir, penguatan tata kelola kurikulum, pendalaman dan perluasan materi, penguatan proses pembelajaran, dan penyesuaian beban belajar agar dapat menjamin kesesuaian antara apa yang diinginkan dengan apa yang dihasilkan. Pengembangan kurikulum menjadi amat penting sejalan dengan kontinuitas kemajuan ilmu pengetahun, teknologi, dan seni budaya serta perubahan masyarakat pada tataran local, nasional, regional, dan global di masa depan. Aneka kemajuan dan perubahan itu melahirkan tantangan internal dan eksternal pada bidang pendidikan. (Rusman, 2018)

Sebagai pelaksana pendidikan guru menjadi sorotan, karena guru merupakan ujung tombak dari setiap kebijakan atau yang berkaitan dengan pendidikan. Gurulah yang akan melaksanakan secara operasional segala bentuk pola, gerak dan geliatnya perubahan dalam dunia pendidikan. Ketika berbagai model pembelajaran yang berkaitan dengan kurikulum misalnya, gurulah yang sangat berperan dalam melaksanakannya. Mengingat peran besar guru tersebut, guru dituntut untuk memberikan sebesarbesarnya kepada pengembangan dan mutu pendidikan. Tapi persoalannya, keadaan guru sendiri belum banyak mendukung kearah itu, baik 


\section{Jurnal Ilmiah Ekonomi Islam, 7(01), 2021, 434}

menyangkut kualitas, profesionalisme, kuantitas maupun kesejahterannya.

Dalam berlangsungnya proses pendidikan di sekolah, selain peran kepala sekolah juga peran pengawas atau supervisor menjadi bagian yang juga menjadi penentu dalam meningkatkan prestasi belajar dan kualitas sekolah. Pengawasan atau supervisi pendidikan adalah usaha untuk memberikan layanan kepada stakeholder pendidikan, terutama kepada pendidik disekolah, baik secara individu maupun secara kelompok guna memperbaiki kualitas proses dan hasil pembelajaran (Sudjana, 2012).

Selanjutnya, Kellen, Roy dalam bukunya yang berjudul Effective teaching Strategies mengemukakan bahwa ada dua pendekatan dalam kegiatan pembelajaran yaitu (1) Pendekatan pembelajaran berorientasi pada guru (teacher centered apporoaches) atau disebut juga kegiatan belajar klasik, dan (2) Pendekatan pembelajaran berorientasi pada siswa (Student Centered Approaches) dengan nama lain kegiatan belajar modern. (Kellen, 2007).

Demikian pula bagi pengawas sekolah, pengawas sekolah juga memiliki kontribusi penting dalam pembelajaran abad 21. Kompetensi pengawas sekolah perlu terus diperbaharui seiring dengan tuntutan perubahan peran strategisnya. Diantara tantangan bagi pengawas sekolah adalah mereka harus berorientasi tidak hanya pada tuntutan keterampilan di abad 21 tetapi juga mempertimbangkan manajemen pembelajaran dalam aspek Pembelajaran Sosial \& Virtual (Vichian dalam Mirfani, 2019).

Dalam pelaksanaan kurikulum 2013, guru dituntut untuk selalu kreatif dan inovatif agar mampu merancang kegiatan yang memfasilitasi siswa untuk berpikir dan belajar, sehingga dapat menghasilkan murid yang berkualitas. Sebagai wujud dari pemaknaan tentang peran guru tersebut, pemerintah telah banyak mengadakan pelatihan atau diklat kurikulum 2013. Di era ini,dunia pendidikan ditantang untuk mampu menghasilkan sumber daya pemikir yang mampu ikut membangun tatanan sosial dan ekonomi untuk sadar pengetahuan sebagaimana layaknya warga dunia di abad 21. Dalam tulisan Sbderstrbrm dkk (2011), dinyatakan bahwa dalam kurun waktu 20 tahun terakhir telah terjadi pergeseran pembangunan pendidikan kearah ICT (Information and Communication Technology) sebagai salah satu strategi manajemen pendidikan abad 21 yang didalamnya meliputi tata kelola kelembagaan dan sumber daya manusia.
Hal serupa juga harus dilakukan oleh kepala madrasah untuk menghadapi tantangan globalisasi abad 21 di dunia pendidikan yang sesuai dengan tatanan sistem pendidikan nasional.. Kepala madrasah sebagai pemimpin harus memiliki visi teknologi yang jelas bersama-sama dengan komunitas sekolah dan pemangku kepentingan sekolah. Dalam hal dukungan teknologi dan infrastruktur di sekolah, Kepala madrasah harus menyediakan peralatan teknologi dan dukungan teknis untuk sekolah. Selain itu, kepala sekolah juga perlu memberikan kesempatan yang sama kepada guru untuk mendapatkan sumber daya teknologi dan memastikan fasilitas yang sesuai untuk mendukung teknologi.

Profesionalisme dalam dekade terakhir ini menjadi permasalahan yang urgen dan dijadikan setiap pemberdayaan guru dalam meningkatkan mutu pendidikan di Indonesia saat ini maka peneliti tertarik membahas manajemen pengembangan kompetensi profesional guru ini sebagai upaya untuk ikut andil di dalam memberikan dunia pendidikan khususnya manajemen pengembangan kompetensi profesional guru mata pelajaran Pendidikan Agama Islam pada MTs di Kabupaten Demak. Berdasarkan latar belakang kondisi guru madrasah, dapat dilihat pentingnya mengetahui manajemen pengembangan kompetensi profesional guru.

\section{METODE PENELITIAN}

Penelitian ini dilaksanakan melalui pendekatan kualitatif dengan menggunakan metode deskriptif. Penelitian ini dilakukan dengan menggunakan pendekatan kualitatif menggunakan strategi studi kasus. Penelitian ini menggambarkan atau mendeskripsikan fenomena pengembangan kompetensi guru dalam manajemen kelas. Penelitian ini dilaksanakan pada situasi alami, bisa dikatakan apa adanya dan tidak dimanipulasi peneliti. Karakteristik dari penelitian ini adalah : (a) mempunyai latar belakang alamiah, (b) peneliti tidak sebagai objek penelitian (c) metode yang digunakan adalah kualitatif, (d) menggunakan analisis data secara induktif, (e) menggunakan teori dasar, (f) data yang dikumpulkan bersifat deskriptif, (g) lebih mementingkan segi proses dari pada hasil, (h) adanya batas yang ditentukan, (i) adanya alat ukur khusus untuk keabsahan data, (j) desain disusun secara sementara, (k) hasil penelitian dirundingkan dan disepakati bersama. 


\section{Jurnal Ilmiah Ekonomi Islam, 7(01), 2021, 435}

Teknik pengumpulan data dengan wawancara, observasi dan studi dokumentasi. Teknik pengumpulan data yang digunakan dalam penelitian ini adalah : (1) wawancara, (2) observasi, (3) dokumentasi. Hal ini sesuai dengan pendapat Sugiyono (2010:309) bahwa penelitian kualitatif secara umum terdapat empat teknik pengumpulan data, yaitu data dikumpulkan melalui teknik (1) observasi atau pengamatan, (2) wawancara, (3) dokumentasi, dan (4) triangulasi atau gabungan.

Keabsahan data adalah usaha meningkatkan derajat kepercayaan data apakah data tersebut dapat dipertanggung jawabkan atau tidak. Untuk meningkatkan derajat keabsahan data agar dapat dipertanggung jawabkan secara optimal maka perlu ada uji keabsahan data. Uji keabsahan data dilakukan dengan memperpanjang partisipasi, ketekunan pengamatan, triangulasi, pengecekan sejawat, kajian kasus negative dan pengecekan anggota (Molleong, 2007:324).

\section{HASIL DAN PEMBAHASAN}

\section{Manajemen Pengembangan Madrasah}

Manajemen merupakan subjek yang sangat penting dalam organisasi yang berfungsi sebagai alat untuk menetapkan tujuan dan mempertimbangkan aspek positif antara masukan (input) dan keluaran (output) agar tercapai efektivitas organisasi dan produktivitas organisasi dengan memadukan semua jenis investasi yang dilakukan manajer dan pegawai dalam melaksanakan aktivitas sesuai dengan kapasitasnya dalam organisasi secara serasi dan seimbang. (Dali, 2017; 27).

Pada perkembangannya, manajemen saat ini menjadi sebuah proses untuk membantu tercapainya efektifitas dan efisiensi dalam bekerja. Menurut pandangan, Hitt, Black dan Porter bahwa : 1) management is a process: it involves a series of actifities and operation, such a planning, deciding and evaluating. 2) management involves assembling as using sets of resources; human, financial, material, and informational. 3) management involves acting in a goal directed manner to accomplish task, 4) management involves activities successfully to achieve particular levels of desired results. (Hitt, etc., 2012;4)

Terry dalam Zulkarnain Dali dalam buku Manajemen Mutu Madrasah menjelaskan bahwa Manajemen adalah proses kegiatan inti (perencanaan, pengorganisasian, pelaksanaan dan pengawasan) sebagai langkah pemberdayaan seluruh sumber dan potensi manajemen baik manusia, metode, material, sarana dan prasarana maupun keuangan agar dapat mencapai tujuan organisasi. Proses ini mencakup kegiatan yang dilakukan individu-individu untuk mencapai tujuan, melalui upaya atau tindakantindakan yang telah ditetapkan sebelumnya. (Dali, 2017 ; 28)

Fungsi-fungsi manajemen adalah elemen-elemen dasar yang akan selalu ada dan melekat di dalam proses manajemen yang akan dijadikan acuan oleh manajer. Menurut Manulang fungsi-fungsi manajemen adalah serangkaian tahap kegiatan atau pekerjaan sampai akhir tercapainya tujuan kegiatan atau pekerjaan. $(2002 ; 27)$.

Manajemen Dakwah menjelaskan bahwa fungsi manajemen adalah rangkaian berbagai kegiatan yang telah ditetapkan dan memiliki hubungan saling ketergantungan antara yang satu dengan yang lainnya yang dilaksankan oleh orang-orang dalam organisasi atau bagian-bagian yang diberi tugas untuk melaksanakan kegiatan. Jika manajemen mnejadi pusat utama bagi kerja individu atau kelompok, maka peran manajemen sangat penting untuk mengatur keberlangsungan kegiatan tersebut di masa depan. (Munir, 2015)

\section{Pengembangan Kompetensi Pendidik}

Kompetensi secara harfiah dapat diartikan sebagai kemampuan. Kemampuan seorang guru dalam mentranfer ilmu yang dimiliki kepada anak didik. Dengan kemampuan tersebut tentulah dengan mudah pula anak didik menerima ilmu yang disajika oleh guru. Kompetensi bukan hanya dalam penguasaan bahan ajar, namun juga kompetensi dalam berperilaku baik dalam lingkungan sekolah maupun di luar sekolah. Guru yang kompeten akan memberikan inspirasi dan kepercayaan diri terhadap rekan kerja, orang tua anak didik, dan anak didik itu sendiri. Kompetensi adalah benih-benih kemampuan yang senantiasa dipupuk dan disiram melalui berbagai proses pembelajaran dan pelatihan. Guru yang memiliki kompeten adalah merupakan sosok manusia yang senantiasa merasa dirinya kekurangan untuk menimba ilmu dan pengalaman. Kompetensi dibentuk oleh kebiasaan dan keberanian mengambil keputusan. Guru yang kompeten tidak lahir begitu saja, tetapi ia merupakan perjalanan yang panjang dari sebuah karier kehidupannya. Kompetensi guru menunjukkan profesionalisme dirinya. (Rimang, 2011;14). 


\section{Jurnal Ilmiah Ekonomi Islam, 7(01), 2021, 436}

Pengembangan kompetensi guru merupakan bagian dari menejemen pengembangan sumberdaya manusia yang menjadi suatu kebutuhan pokok dalam sebuah organisasi baik formal maupun non formal. Hal ini merupakan suatu investasi bagi organisasi, dan akan berimplikasi terhadap pembangunan sumberdaya manusia suatu bangsa. Diantara tujuan dari sebuah pengembangan ini adalah untuk meningkatkan kualitas manusia Indonesia yang menguasai pengetahuan, keterampilan, keahlian serta wawasan yang sesuai dengan perkembangan Iptek. Wawasan yang diperlukan dalam era globalisasi dalam kemampuan untuk memandang jauh ke depan, wawasan mutu dan kekaryaan, serta wawasan perubahan yang sesuai dengan nilai-nilai yang berkembang dalam masyarakat. Pengembangan profesi adalah upaya gigih, ulet dan tabah dari seorang guru serta pengawas yang terus menerus memaksimalkan mengindentifikasikan dan menyelesaikan permasalahan serta memantapkan kemajuan pendidikan, khususnya di sekolah tempat bertugas. Baik untuk kepentingan pembinaan kelembagaan, kurikulum kesiswaan, guru, metodologi, media, pendanaan, evaluasi, kerjasama dengan orang tua peserta didik, dan lingkungan masyarakat. (Trianto, 2010:77)

Peningkatan mutu sumber daya manusia keguruan melalui pengembangan profesi, peningkatan kualitas sumber daya manusia dapat dilakukan melalui pengamalan agama, peningkatan kesejahteraan, peningkatan pendidikan, peningkatan pelatihan, peningkatan kesehatan, peningkatan kesempatan kerja, pengendalian kependudukan, peningkatan lingkungan hidup dan perencanaan karier.

Ada lima macam kegiatan guru yang termasuk kegiatan pengembangan profesi, yaitu:

Pertama, melaksanakan kegiatan karya tulis/karya ilmiah di bidang pendidikan

Kedua, menemukan teknologi tepat guna di bidang pendidikan

Ketiga, membuat alat pelajaran/peraga atau alat bimbingan

Keempat, menciptakan karya seni

Kelima, mengikuti kegiatan pengembangan kurikulum.

Lahirnya UU No. 14 Tahun 2005 merupakan salah satu usaha untuk meningkatkan mutu guru, sekaligus diharapkan dapat meningkatkan mutu pendidikan di Indonesia. Di dalam UU ini diamantkan bahwa guru wajib memiliki kualifikasi akademik, kompetensi, sertifikat pendidik, sehat jasmani dan ruhani, serta memiliki kemampuan untuk mewujudkan tujuan pendidikan nasional. Kebijakan prioritas dalam kerangka pemberdayaan guru saat ini adalah meningkatkan kualifikasi, peningkatan kompetensi, sertifikasi guru, penembangan karier, penghargaan dan perlindungan, perencanaan kebutuhan guru, tunjangan guru, dan maslahat tambahan.

\section{Profesional Guru di Madrasah}

Menurut UURI No. 14/2005 Pasal ayat 4, profesional adalah pekerjaan atau kegiatan yang dilakukan oleh seseorang dan menjadi sumber penghasilan kehidupan yang memerlukan keahlian, kemahiran atau kecakapan yang memenuhi standar mutu atau norma tertentu serta memerlukan pendidikan profesi. Profesional berarti persyaratan yang memadai sebagai suatu profesi. Pekerjaan profesional berbeda dengan pekerjaan lainnya karena suatu profesi memerlukan keahlian lain, pekerjaan yang bersifat profesional adalah pekerjaan yang hanya dapat dipersiapkan untuk itu. Jadi profesional adalah orang yang melaksanakan tugas profesi keguruan dengan penuh tangung jawab dan dedikasi tinggi dengan sarana penunjang berupa bekal pengetahuan yang dimilikinya sesuai dengan standard yang telah ditetapkan (Suprihatiningrum, 2020).

Guru profesional adalah guru yang memiliki keahlian, tanggung jawab, dan rasa kesejawatan yang didukung oleh etika profesi yang kuat. Untuk itu hendaknya para guru telah memiliki kualifikasi kompetensi yang memadai yang meliputi kompetensi intelektual, social, spiritual, pribadi, moral dan profesional. Dalam hubungan ini perlu diupayakan berbagai tindakan kegiatan nyata agar para guru dapat berkembang ke arah penguasaan kompetensi profesional sebagai landasan unjuk kerjanya. Unjuk kerja secara profesional mencakup berbagai dimensi secara terpadu, yaitu filosofi, konseptual, dan operasional. (Isjoni, 2009).

Sebagai tenaga professional, guru berperan dalam melaksanakan sistem pendidikan nasionl dan mewujudkan tujuan pendidikan nasional, yaitu berkembangnya potensi siswa agar menjadi manusia yang beriman dan bertakwa kepada Tuhan Yang Maha Esa, berakhlak mulia, sehat, berilmu, cakap, kreatif, mandiri, serta menjadi warga Negara yang demokratis dan bertanggung jawab (Pasal 6 UUGD No.14/2005). 


\section{Jurnal Ilmiah Ekonomi Islam, 7(01), 2021, 437}

Profesionalisme guru dianggap berperan penting dalam membantu perkembangan peserta didik untuk mewujudkan tujuan hidupnya secara optimal. Karena hanya guru yang professional, ia mampu menjalankan tugas dan fungsinya secara maksimal dalam membina akhlak mulia peserta didik. Suatu keniscayaan akan muncul karena manusia adalah makhluk lemah dan tidak berdaya yang dalam perkembangan senantiasa membutuhkan orang lain, demikian juga dengan peserta didik. Peserta didik membutuhkan peran orang lain, dalam hal ini adalah guru yang dapat membimbing dan mengarahkan, sehingga peserta didik mendapatkan pengetahuan sebagai pedoman hidupnya (Mulyasa, 2008).

Tabel Standar Kompetensi Guru Mata Pelajaran Di SD/MI, SMP/MTs, SMA/MA, Dan SMK/MAK

\begin{tabular}{|c|c|c|}
\hline No. & KOMPETENSI INTI GURU & KOMPETENSI GURU MATA PELAJARAN \\
\hline \multicolumn{3}{|c|}{ Kompetensi Pedagogik } \\
\hline 1. & $\begin{array}{l}\text { Menguasai karakteristik peserta } \\
\text { didik dari aspek fisik, moral, } \\
\text { spiritual, sosial, kultural, } \\
\text { emosional, dan intelektual. }\end{array}$ & $\begin{array}{l}\text { 1.1. Memahami karakteristik peserta didik yang berkaitan dengan aspek } \\
\text { fisik, intelektual, sosial-emosional, moral-spiritual dan latar } \\
\text { belakang social-budaya. } \\
\text { 1.2. } \begin{array}{l}\text { Mengidentifikasi potensi peserta didik dalam mata pelajaran yang } \\
\text { diampu. }\end{array} \\
\text { 1.3. } \begin{array}{l}\text { Mengidentifikasi bekal-ajar awal peserta didik pada mata pelajaran } \\
\text { yang diampu. } \\
\text { 1.4. Mengidentifikasi kesulitan belajar peserta didik dakam mata } \\
\text { pelajaran yang diampu. }\end{array}\end{array}$ \\
\hline
\end{tabular}

2. Menguasai teori belajar dan 2.1. Memahami berbagai teori belajar dan prinsip-prinsip pembelajaran prinsip-prinsip pembelajaran yang mendidik terkait dengan mata pelajaran yang diampu.

yang mendidik

2.2. Menerapkan berbagpem belafasrai kegiatan, strategi, metode, dan teknik pembelajaran yang mendidik secara kreatif dalam mata pelajaran yang diampu

3. Mengembangkan kurikulum 3.1. Memahami prinsip-prinsip pengembangan kurikulum

yang terkait dengan mata 3.2. Menetukan tujuan pembelajaran yang diampu

pelajaran yang diampu

3.3. Menentukan pengalaman belajar yang sesuai untuk mencapai tujuan pembelajaran yang diampu

3.4. Memilih materi prmbelajarn yang diampu yang terkait dengan pengalaman belajar dan tujuan pembelajaran.

3.5. Menata materi pembelajaran secara benar sesuai dengan pendekatan yang dipilih,

3.6. Mengembangkan indikator dan instrument penilaian

4. Menyelenggarakan pembelajaran yang mendidik
4.1. Memahami prinsip-prinsip perancangan pembelajaran yang mendidik

4.2. Mengembangkan komponen-komponen rancangan pembelajaran

4.3. Menyusun rancangan pembelajaran yang lengkap, baik untuk kegiatan di dalam kelas, laboratorium, maupun lapangan

4.4. Melaksanakan pembelajaran yang mendidik di kelas, di laboratorium dan di lapangan dengan memperhatikan standar keamanan yang dipersyaratkan

4.5. Menggunakan media pembelajaran dan sumber belajar yang relevan dengan karakteristik peserta didik dan mata pelajaran yang diampu untuk mencapai tujuan pembelajaran secara utuh

4.6. Mengambil keputusan transaksional dalam pembelajaran yang diampu sesuai dengan situasi yang berkembang teknologi5.1. Memanfaatkan teknologi informasi dan komunikasi dalam pembelajaran yang diampu kepentingan pembelajaran 
Jurnal Ilmiah Ekonomi Islam, 7(01), 2021, 438

\begin{tabular}{|c|c|c|}
\hline No. & KOMPETENSI INTI GURU & KOMPETENSI GURU MATA PELAJARAN \\
\hline 6. & $\begin{array}{l}\text { Memfasilitasi pengembangan } \\
\text { potensi peserta didik untuk } \\
\text { mengaktualisasikan berbagai } \\
\text { potensi yang dimiliki }\end{array}$ & $\begin{array}{l}\text { 6.1. Menyediakan berbagai kegiatan pembelajaran untuk mendorong } \\
\text { peserta didik mencapai prestasi secara optimal } \\
\text { 6.2. Menyediakan berbagai kegiatan pembelajaran untuk } \\
\text { mengaktualisasikan potensi peserta didik, termasuk kreativitasnya }\end{array}$ \\
\hline 7. & $\begin{array}{l}\text { Berkomunikasi secara efektif, } \\
\text { empatik, dan santun dengan } \\
\text { peserta didik }\end{array}$ & $\begin{array}{l}\text { 7.1. Memahami berbagai strategi berkomunikasi yang efektif, empatik, } \\
\text { dan santun, secara lisan, tulisan, dyang khas dan/atau bentuk lain } \\
\text { 7.2. Berkomunikasi secara efektif, empatik, dan santun dengan peserta } \\
\text { didik dengan bahasa yang khas dalam interaksi kegiatan/permainan } \\
\text { yang mendidik yang terbangun secara siklikal dari (a) penyiapan } \\
\text { kondisi psikologis peserta didik untuk ambil bagian dalam } \\
\text { permainan melalui bujukan dan contoh, (b) ajakan kepada peserta } \\
\text { didikuntuk ambil bagian, } \\
\text { guru, dan (c) respon peserta didik terhadap ajakan } \\
\text { seterusnya }\end{array}$ \\
\hline
\end{tabular}

8. Menyelenggarakan penilaian 8.1. Memahami prinsip-prinsip penilaian dan evaluasi proses dan hasil dan evaluasi proses dan hasi belajar sesuai dengan karakteristik mata pelajaran yang diampu belajar

8.2. Menentukan aspek-aspek proses dan hasil belajar yang penting untuk dinilai dan dievaluasi sesuai dengan karekteristik mata pelajaran yang diampu

8.3. Menentukan prosedur penilaian dan evaluasi proses dan hasil belajar

8.4. Mengembangkan instrument penilaian dan evaluasi proses dan hasil belajar

8.5. Mengadministrasikan penilaian proses dan hasil belajar secara berkesinambungan dengan menggunakan berbagai instrumen

8.6. Menganalisis hasil penilaian proses dan hasil belajar untuk berbagai tujuan

8.7. Melakukan evaluasi proses dan hasil belajar

9. Memanfaatkan hasil penilaian 9.1. Menggunakan informasi hasil penilaian dan evaluasi untuk dan evaluasi untuk kepentingan pembelajaran menentukan ketuntasan belajar

9.2. Menggunakan informasi hasil penilaian dan evaluasi untuk merancang program remedial dan pengayaan

9.3. Mengkomunikasikan hasil penilaian dan evaluasi kepada pemangku kepentingan

9.4. Memanfaatkan informasi hasil penilaian dan evaluasi pembelajaran untuk meningkatkan kualitas pembelajaran

10. Melakukan tindakan reflektif 10.1. Melakukan refleksi terhadap pembelajaran yang telah dilaksanakan untuk peningkatan kualitas 10.2. Memanfaatkan hasil refleksi untuk perbaikan dan pengembangan pembelajaran pembelajaran dalam mata pelajaran yang diampu

10.3. Melakukan penelitian tindakan kelas untuk meningkatkan kualitas pembelajaran dalam mata pelajaran yang diampu

\section{Kompetensi Kepribadian}

11. Bertindak sesuai dengan norma11.1. Menghargai peserta didik tanpa membedakan keyakinan yang agama, hukum, sosial dan dianut, suku, adat istiadat, daerah asal, dan gender

kebudayaan nasional Indonesia 11.2. Bersikap sesuai dengan norma agama yang dianut, hokum dan social yang berlaku dalam masyarakat, dan kebudayaan nasional Indonesia yang beragam

12. Menampilkan diri sebagai 12.1. Berperilaku jujur, tegas, dan manusiawi

pribadi yang jujur, berakhlak12.2. Berperilaku yang mencerminkan ketakwaan dan akhlak mulia 
Jurnal Ilmiah Ekonomi Islam, 7(01), 2021, 439

\begin{tabular}{|l|l|c|}
\hline No. & KOMPETENSI INTI GURU & KOMPETENSI GURU MATA PELAJARAN \\
\hline $\begin{array}{l}\text { mulia, dan teladan bagi peserta } \\
\text { didik dan masyarakat }\end{array}$ & $\begin{array}{l}\text { 12.3. } \\
\text { Berperilaku yang dapat diteladani oleh peserta didik dan anggot } \\
\text { masyarakat di sekitarnya }\end{array}$ \\
\hline
\end{tabular}

13. Menampilkan diri sebagai 13.1. Menampilkan diri sebahai pribadi yang mantap dan stabil pribadi yang mantap, stabil, 13.2. Menampilkan diri sebagai pribadi yang dewasa, arif dan berwibawa dewasa, arif, dan berwibawa

14. Menunjukkan etos kerja. 14.1. Menunjukkan etos kerja, tangung jawab yang tinggi tanggung jawab yang tinggi, rasa 14.2. Bangga menjadi guru dan percaya pada diri sendiri bangga menjadi guru, dan rasa14.3. Bekerja mandiri secara professional percaya diri

15. Menjunjung tinggi kode etik15.1. Memahami kode etik profesi guru profesi guru

15.2. Menerapkan kode etik profesi guru

15.3. Berperilaku sesuai dengan kode etik profesi guru

\section{Kompetensi Sosial}

16. Bersikap inklusif, bertindak 16.1. Bersikap inklusif dan objektif terhadap peserta didik, teman objektif, serta tidak diskriminatif sejawar dan lingkungan sekitar dalam melaksanakan pembelajaran karena pertimbangan jenis 16.2. Tidak bersikap diskriminatif terhadap peserta didik, teman kelamin, agama, ras, kondisi fisik, latar belakang keluarga. dan status social ekonomi sejawat, orang tua peserta didik dan lingkungan sekolah karena perbedaan agama, suku, jenis kelamin, latar belakang keluarga, dan status sosial-ekonom

\begin{tabular}{l|l} 
No. & KOMPETENSI INTI GURU \\
\hline
\end{tabular}

KOMPETENSI GURU MATA PELAJARAN

17. Berkomunikasi secara efektif, 17.1. Berkomunikasi dengan teman sejawat dan komunitas ilmiah empatik, dan santun dengan lainnya secara santun, empatik dan efektif

sesama pendidik, tenaga 17.2. Berkomunikasi dengan orang tua peserta didik dan masyarakat kependidikan, orang tua, dan masyarakat secara santun, empatik dan elektif tentang program pembelajaran dan kemajuan peserta didik

17.3. Mengikutsertakan orang tua peserta didik dan masyarakat dalam program pembelajaran dan dalam mengatasi kesulitan belajar peserta didik

18. Beradaptasi di tempat bertugas di 18.1. Beradaptasi dengan lingkungan tempat bekerja dalam rangka seluruh wilayah Republik meningkatkan efektivitas sebagai pendidik

Indonesia yang memiliki 18.2. Melaksanakan berbagai program dalam lingkungan kerja untuk keragaman social budaya mengembangkan dan emningkatkan kualitas pendidikan di daerah yang bersangkutan

19 Berkomunikasi dengan 19.1.Berkomunikasi dengan teman sejawat profesi ilmiah, dan komunitas komunitas profesi sendiri dan profesi lain secara lisan dan tulisan atau bentuk lain ilmiah lainnya melalui berbagai media dalam rangka meningkatkan kualitas pembelajaran

19.2.Mengkomunikasikan hasil-hasil inovasi pembelajaran kepada komunitas profesi sendiri secara lisan dan tulisan maupun bentuk lain

\section{Kompetensi Profesional}

20 Menguasai materi, struktur.Jabaran kompetensi Butir 20 untuk masing-masing guru mata pelajaran konsep, dan pola pikir keilmuandisajikan setelah tabel ini yang mendukung mata pelajaran yang diampu

21 Menguasai standar kompetensi21.1. Memahami standar kompetensi mata pelajaran yang diampu dan kompetensi dasar mata 21.2. Memahami kompetensi dasar mata pelajaran yang diampu pelajaran yang diampu

21.3. Memahami tujuan pembelajaran yang diampu 


\begin{tabular}{|c|c|c|}
\hline \multicolumn{3}{|c|}{ Jurnal Ilmiah Ekonomi Islam, 7(01), 2021, 440} \\
\hline No. & KOMPETENSI INTI GURU & KOMPETENSI GURU MATA PELAJARAN \\
\hline 22 & $\begin{array}{l}\text { Mengembangkan materi } \\
\text { pembelajaran yang diampu } \\
\text { secara kreatif }\end{array}$ & $\begin{array}{l}\text { 22.1. Memilih materi pembelejaran yang diampu sesuai dengan tingkat } \\
\text { perkembangan peserta didik } \\
\text { 22.2. } \begin{array}{l}\text { Mengolah materi pelajaran yang diampu secara kreatif sesuai } \\
\text { dengan tingkat perkembangan peserta didik }\end{array}\end{array}$ \\
\hline 23 & $\begin{array}{l}\text { Mengembangkan } \\
\text { keprofesionalan secara } \\
\text { berkelanjutan dengan melakukan } \\
\text { tindakan reflektif }\end{array}$ & $\begin{array}{l}\text { 23.1. Melakukan refleksi terhadap kinerja sendiri secara terus menerus } \\
\text { 23.2. Memanfaatkan hasil refleksi dalam rangka peningkatan } \\
\text { keprofesionalan } \\
\text { 23.3. } \begin{array}{l}\text { Melakukan penelitian tindakan kelas untuk peningkatan } \\
\text { keprofesionalan }\end{array} \\
\text { 23.4. } \text { Mengikuti kemajuan zamandengan belajar dari berbagai sumber }\end{array}$ \\
\hline 24 & $\begin{array}{l}\text { Memanfaatkan teknologi } \\
\text { informasi dan komunikasi untuk } \\
\text { mengembangkan diri }\end{array}$ & $\begin{array}{l}\text { 24.1. Memanfaatkan teknologi informasi dan komunikasi dalam } \\
\text { berkomunikasi } \\
\text { 24.2. } \begin{array}{l}\text { Memanfaatkan teknologi informasi dan komunikasi untuk } \\
\text { pengembangan diri }\end{array}\end{array}$ \\
\hline
\end{tabular}

Profesionalisme dalam dekade terakhir ini menjadi permasalahan yang urgen dan dijadikan setiap pemberdayaan guru dalam meningkatkan mutu pendidikan di Indonesia saat ini maka peneliti tertarik membahas manajemen pengembangan kompetensi profesional guru ini sebagai upaya untuk ikut andil di dalam memberikan dunia pendidikan khususnya manajemen pengembangan kompetensi profesional guru mata pelajaran Pendidikan Agama Islam pada MTs di Kabupaten Demak.

Berdasarkan penelitian terhadap kondisi guru madrasah ini dapat dilihat pentingnya mengetahui manajemen pengembangan kompetensi profesional guru di madrasah. Di Madrasah Tsanawiyah Kabupaten Demak, terlihat bahwa kebijakan yang dibuat baik dari perencanaan, pelaksanaan, pendukung dan penghambat, dan dampak pengembangan kompetensi professional guru yang dilaksanakan berjalan sesuai dengan tujuan dan terencana.

Strategi manajemen pengembangan kompetensi profesionalisme guru. melibatkan berbagai pihak yang memfasilitasi guru. Perencanaan pengembangan kompetensi professional guru dengan membuat pemetaan terhadap guru sesuai kebutuhan pengembangannya, merencanakan program sesuai kebutuhan. Pelaksanaan pengembangan kompetensi professional guru melalui penataran-penataran, pelatihan, supervisi, dll. Faktor pendukung ialah pemerintah yang bekerjasama dengan kementrian agama yang telah menyediakan program memberikan tunjangan sertifikasi profesi, kepala madrasah memberikan supervise dan program pengembangan. Dimana yang menjadi faktor penghambat ialah: dalam pelaksanaanya terkadang terbentur dengan jadwal kegiatan guru dan keterbatasan anggaran dan sistem yang ada yang harus lebih diperbaiki. Dampaknya guru mampu menjalankan tugasnya sebagai pendidik dengan baik dan professional. Serta siswa dapat mengaplikasikan teori yang dipelajarinya, serta prestasi siswa akan meningkat. Madrasah memiliki strategi dan metode pembelajaran yang bervariasi, berbagai program yang mengembangkan pendidikan.

\section{KESIMPULAN}

Manajemen pengembangan kompetensi pada pendidik merupakan bagian dari strategi pengembangan sumberdaya manusia yang menjadi suatu kebutuhan pokok dalam sebuah organisasi baik formal maupun non formal. Hal ini merupakan suatu investasi bagi organisasi dalam hal ini madrasah, yang akan berimplikasi terhadap pembangunan sumberdaya manusia suatu bangsa. Diantara tujuan dari sebuah pengembangan ini adalah untuk meningkatkan kualitas manusia Indonesia yang menguasai pengetahuan, keterampilan, keahlian serta wawasan yang sesuai dengan perkembangan Iptek. Berdasarkan penelitian terhadap kondisi guru madrasah ini dapat dilihat pentingnya mengetahui manajemen pengembangan kompetensi profesional guru di madrasah. Di Madrasah Tsanawiyah Kabupaten Demak, menunjukkan bahwa kebijakan yang dibuat baik dari perencanaan, pelaksanaan, pendukung dan penghambat, dan dampak pengembangan kompetensi professional guru yang dilaksanakan berjalan sesuai dengan tujuan dan terencana. 


\section{UCAPAN TERIMA KASIH}

Terimakasih kami sampaikan kepada dewan redaksi Jurnal Ilmiah Ekonomi Islam ( JIEI) ITB AAS Indonesia yang telah memberikan kesempatan, sehingga tulisan saya bisa diterbitkan.

\section{REFERENSI}

Ahmadi, Rulam (2018). Profesi Keguruan: Konsep dan Strategi Mengembangkan Profesi dan Karier Guru. Yogyakarta: Ar-Ruzz Media.

Alma, Buchori (2012). Guru Profesional: Menguasai Metode dan Terampil Mengajar. Bandung: Alfabeta.

Amalia, Husna (2019). Manajemen Pengembangan Musyawarah Guru Mata Pelajaran (MGMP) sebagai Upaya Meningkatkan Kompetensi Profesional Guru PAI. Jurnal Darussalam; Jurnal Pendidikan, Komunikasi dan Pemikiran Hukum Islam Vol. XI, No 1:132-147. September.

Cahyana, Ade (2010). Pengembangan Kompetensi Profesional Guru dalam Menghadapi Sertifikasi. Jurnal Pendidikan dan Kebudayaan, Vol. 16, Nomor 1, Jnauari.

Creswell, John W. (2018). Research Design: Pendekatan Metode Kualitatif, Kuantitatif, dan Campuran. Yogyakarta: Pustaka Pelajar

Dali, Zulkarnain (2017). Manajemen Mutu Madrasah. Yogyakarta: Pustaka Pelajar.

Danim, Sudarwan (2015). Pengembangan Profesi Guru: dari Pra-Jabatan, Induksi ke Profesional Madani. Jakarta: Prenada Media

E. Mulyasa (2008). Menjadi Guru Profesional Menciptakan Pembelajaran Kreatif dan Menyenangkan. Bandung: Remaja Rosdakarya.

Fitriani, Cut, dkk. Kompetensi Profesional Guru dalam Pengelolaan Pembelajaran di MTs Muhammadiyah Banda Aceh. Jurnal Magister Administrasi Pendidikan Pascasarjana Universitas Syiah Kuala Volume 5, No. 2, Mei 2017 pp. 88 - 95.

Hambali, Muh. (2016). Manajemen Pengembangan Kompetensi Guru PAI. Jurnal MPI Vol 1

Hasbullah (2016). Kebijakan Pendidikan: Dalam Perspektif Teori, Aplikasi dan Kondisi Objektif Pendidikan di Indonesia. Jakarta: Rajawali Press Hermino, Agustinus (2018). Guru dalam Tantangan Globalisasi: Kajian Teoritis dan Praktis dalam Manajemen Pendidikan. Yogyakarta: Ar-Ruzz Media.
Hitt, Michael A., Black J. Stewart dan Porte, Lyman W. (2012). Management. London: Pearson International.

Ikbal, Panji Alam Muhamad (2018). Manajemen Pengembangan Kompetensi Guru. Jurnal Isema; Islamic Educational Manajemen Vol. 3, No 1. P.65-75. Juni.

Isjoni (2009). Guru seabagi Motivator Perubahan. Yogyakarta: Pustaka Pelajar.

Janawi (2019). Kompetensi Guru, Citra Guru Profesional. Bandung: Alfabeta

Kadir, Abdul (2015). Dasar-dasar Pendidikan. Jakarta: Prenada Media

Keputusan Menteri Agama Nomor 183 Tahun 2019 Tentang Kurikulum PAI dan Bahasa Arab pada Madrasah

Keputusan Menteri Agama Nomor 184 Tahun 2019 Tentang Pedoman Implementasi Kurikulum pada Madrasah

Khuluqo, Ihsana El. (2017). Belajar dan Pembelajaran: Konsep Dasar Metode dan Aplikasi Nilai-Nilai Spiritualitas dalam Proses Pembelajaran. Yogyakarta: Pustaka Pelajar.

Kompri (2015). Manajemen Sekolah: Orientasi Kemandirian Kepala Sekolah. Yogyakarta: Pustaka Pelajar

Kosim, Abdul \& Fathurrohman (2018). Pendidikan Agama Islam: Sebagai Core Values untuk Perguruan Tinggi Umum. Bandung: Remaja Rosdakarya

Mahmud (2019) Manajemen Pendidikan Tinggi: Berbasis Nilai-Nilai Spiritualitas. Bandung: Remaja Rosdakarya

Makawimbang, Jerry H. (2012) Kepemimpinan Pendidikan yang Bermutu. Bandung: Alfabeta.

Muhaimin \& Suti'ah \& Prabowo, Sugeng Listyo (2015). Manajemen Pendidikan: Aplikasinya dalam Penyusunan Rencana Pengembangan Sekolah/Madrasah. Jakarta: Prenada Media

Nasution, Sri Purwanti (2016). Peranan Kepala Madrasah terhadap Kinerja Guru dalam Jurnal Al-Idarah Vol, 6, No. 1; Jurnal ilmiah Prodi Manajemen Pendidikan Islam Fakultas Tarbiyah dan Keguruan IAIN Raden Intan Lampung.

Nata, Abuddin (2018). Manajemen Pendidikan, Mengatasi Kelemahan Pendidikan Islam di Indonesia. Jakarta: Prenada Media.

Noor, Juliansyah (2017). Metodologi Penelitian. Jakarta: Kencana. 
Peraturan Pemerintah Republik Indonesia No. 74 Tahun 2008 tentang Guru

Peraturan Pemerintah Republik Indonesia Nomor 19

Tahun 2017 tentang Perubahan Atas Peraturan

Pemerintah Republik Indonesia Nomor 74 Tahun 2008 tentang Guru

Sanjaya, Wina (2015). Pembelajaran dalam Implementasi Kurikulum Berbasis Kompetensi. Jakarta: Prenada Media.

Setyosari, Punaji (2016). Metode Penelitian Pendidikan dan Pengembangan. Jakarta: Prenada Media.

Siadari, Halomoan Mangasi ((2013). Manajemen Pengembangan Profesionalisme Guru di SMP Negeri 3 Jetis Bantul. Jurnal Akuntabilitas Manajemen Pendidikan Volume 1, Nomor 1. P. $48-65$.

Sudarman, Momon (2013). Profesi Guru, Dipuji, Dikritis, dan Dicaci. Jakarta: Rajawali Press.

Suprihatiningrum, Jamil (2020). Guru Profesional:

Pedoman Kinerja, Kualifikasi, dan Kompetensi Guru. Yogyakarta: Ar-Ruzz Media.

Sugiyono. (2010). Memahami Metode Penelitian Kualitatif. Bandung: Alfabeta.

Sumadi, S. (2017). Peran Manajemen Syariah Terhadap Peningkatan Kepuasan Pelanggan Pada Rumah Sakit Islam Di Kota Surakarta. Jurnal Ilmiah Ekonomi Islam, 3(02), 112-124.

Trianto (2010). Model Pembelajaran Terpadu: Konsep, Strategi dan Implementasinya dalam Kurikulum Tingkat Satuan Pendidikan (KTSP). Jakarta: Bumi Aksara
Trisoni, Ridwal (2011). Pengembangan Profesionalisme Guru dalam Mewujudkan Kualitas Pendidikan. Jurnal Ta'dib, Volume 14, No. 2. Desember.

Tohirin (2014). Psikologi Pembelajaran Pendidikan Agama Islam: Berbasis Integrasi dan Kompetensi. Jakarta: Rajawali Press.

Undang-Undang Republik Indonesia No. 20 tahun 2003 tentang Sistem Pendidikan Nasional

Undang-Undang Republik Indonesia No. 14 Tahun 2005 tentang Guru dan Dosen

Uno, Hamzah B. (2012) Profesi Kependidikan: Problrma, Solusi dan Reformasi di Indonesia. Jakarta: Bumi Aksara.

Wibowo, Agus (2016). Manajemen Pendidikan Karakter di Sekolah: Konsep dan Praktik Implementasi. Yogyakarta: Pustaka Pelajar

Widodo, Suparno Eko (2018). Manajemen Pengembangan Sumber Daya Manusia. Yogyakarta: Pustaka Pelajar

Winarni, Endang Widi. (2018). Teori dan Praktik Penelitian Kuantitatif Kualitatif: Penelitian Tindakan Kelas (PTK) Research and Development (R\&D).

Yusuf, Muri (2017) Metode Penelitian: Kuantatif, Kualitatif dan Penelitian Gabungan. Jakarta: Kencana 